\title{
Interstitial Leydig Cell Tumorigenesis-Leptin and Adiponectin Signaling in Relation to Aromatase Expression in the Human Testis
}

\author{
Michal Duliban ${ }^{1}$, Ewelina Gorowska-Wojtowicz ${ }^{1, *} \mathbb{C}^{\mathbb{D}}$, Waclaw Tworzydlo ${ }^{2}{ }^{\mathbb{D}}$, Agnieszka Rak ${ }^{3} \mathbb{C}_{\text {, }}$ \\ Malgorzata Brzoskwinia ${ }^{1}$, Izabella Krakowska ${ }^{4}$, Jan K. Wolski ${ }^{5}$, Malgorzata Kotula-Balak ${ }^{4, *}$, \\ Bartosz J. Płachno ${ }^{6} \mathbb{D}$ and Barbara Bilinska ${ }^{1}$ \\ 1 Department of Endocrinology, Institute of Zoology and Biomedical Research, Jagiellonian University in \\ Krakow, Gronostajowa 9, 30-387 Krakow, Poland; michal.duliban@doctoral.uj.edu.pl (M.D.); \\ malgorzata.brzoskwinia@doctoral.uj.edu.pl (M.B.); barbara.bilinska@uj.edu.pl (B.B.) \\ 2 Developmental Biology and Invertebrate Morphology, Institute of Zoology and Biomedical Research, \\ Jagiellonian University in Krakow, Gronostajowa 9, 30-387 Krakow, Poland; w.tworzydlo@uj.edu.pl \\ 3 Department of Physiology and Toxicology of Reproduction, Institute of Zoology and Biomedical Research, \\ Jagiellonian University in Krakow, Gronostajowa 9, 30-387 Krakow, Poland; agnieszka.rak@uj.edu.pl \\ 4 University Centre of Veterinary Medicine, University of Agriculture in Krakow, Mickiewicza 24/28, 30-059 \\ Krakow, Poland; Izabella.krakowska@urk.edu.pl \\ 5 nOvum Fertility Clinic, Bociania 13, 02-807 Warszawa, Poland; jkwolski@op.pl \\ 6 Department of Plant Cytology and Embryology, Institute of Botany, Jagiellonian University in Krakow, \\ Gronostajowa 9, 30-387 Krakow, Poland; bartosz.plachno@uj.edu.pl \\ * Correspondence: ewelina.gorowska@uj.edu.pl (E.G.-W.); malgorzata.kotula-balak@urk.edu.pl (M.K.-B.)
}

Received: 26 March 2020; Accepted: 15 May 2020; Published: 21 May 2020

Abstract: Although epidemiological studies from the last years report an increase in the incidences of Leydig cell tumors (previously thought to be a rare disease), the biochemical characteristics of that tumor important for understanding its etiology, diagnosis, and therapy still remains not completely characterized. Our prior studies reported G-protein coupled estrogen receptor signaling and estrogen level disturbances in Leydig cell tumors. In addition, we found that expressions of multi-level-acting lipid balance- and steroidogenesis-controlling proteins including peroxisome proliferator-activated receptor are altered in this tumor. In order to get deeper into the other molecular mechanisms that regulate lipid homeostasis in the Leydig cell tumor, here we investigate the presence and expression of newly-described hormones responsible for lipid homeostasis balancing (leptin and adiponectin), together with expression of estrogen synthase (aromatase). Samples of Leydig cell tumors $(n=20)$ were obtained from patients (31-45 years old) and used for light and transmission electron microscopic, western blotting, and immunohistochemical analyses. In addition, body mass index (BMI) was calculated. In tumor mass, abundant lipid accumulation in Leydig cells and various alterations of Leydig cell shape, as well as the presence of adipocyte-like cells, were observed. Marked lipid content and various lipid droplet size, especially in obese patients, may indicate alterations in lipid homeostasis, lipid processing, and steroidogenic organelle function in response to interstitial tissue pathological changes. We revealed significantly increased expression of leptin, adiponectin and their receptors, as well as aromatase in Leydig cell tumors in comparison to control. The majority of patients ( $n=13$ ) were overweight as indicated by their BMI. Moreover, a significant increase in expression of phospholipase C (PLC), and kinases Raf, ERK which are part of adipokine transductional pathways, was demonstrated. These data expand our previous findings suggesting that in human Leydig cell tumors, estrogen level and signaling, together with lipid status, are related to each other. Increased BMI may contribute to certain biochemical characteristics and function of the Leydig cell in infertile patients with a tumor. In addition, altered adipokine-estrogen microenvironment can have an effect on proliferation, growth, and metastasis of tumor cells. We report here various targets (receptors, 
enzymes, hormones) controlling lipid balance and estrogen action in Leydig cell tumors indicating their possible usefulness for diagnostics and therapy.

Keywords: adiponectin; aromatase; leptin; Leydig cell tumor; ultrastructure

\section{Introduction}

The discoveries of leptin and adiponectin were the first indications that adipose tissue is an endocrine organ [1]. Today it is known that these major adipokines maintain homeostasis of glucose, lipid, and energy, each contributing to the communication between the adipocyte and other tissues. The signals, in turn, interact with each other to regulate cellular processes. Leptin was the first recognized for its prominent action on the hypothalamus to control food intake, energy expenditure, and body weight [2]. In obese individuals, leptin does not adequately regulate energy expenditure [3]. These patients are referred to as "leptin resistant" due to low basal metabolic rates, despite high circulating leptin [4]. Adiponectin exerts potent effects on the central endocrine axis (brain structures) also regulating energy amount and consumption. Moreover, adiponectin is responsible for encouraging the "healthy" expansion of adipose tissue, thereby preventing ectopic lipid accumulation [5]. Intravenous administration of adiponectin to leptin-deficient mice decreases their thermogenesis and weight [6].

The release of both leptin and adiponectin can be acutely enhanced through a variety of factors [7]. Circulating levels of leptin are proportional to fat mass and number of leptin receptors abundantly expressed in many tissues. It has been demonstrated that the biological activity of leptin strongly depends on its proper interactions with obesity receptors (Ob-R) [8]. Interestingly, adiponectin was originally identified in stomach extracts of cattle as the endogenous ligand of the orphan $G$ protein-coupled receptor APJ [9].

Lipid homeostasis is crucial for function of the endocrine reproductive organs. However, in contrary to the female, not much is known still about the distinct role of adopokines in the male. Recently, adiponectin supervision of lipid accumulation and metabolism in lipid-rich tissues was linked to human reproductive function [7]. It was shown that leptin through its hypothalamic level directly effects on androgen synthesis [10]. In obese patients, increased leptin level was associated with decreased sperm concentration and vitality [11]. Of note, steroid hormone biogenesis from cholesterol (steroidogenesis) constitutes an important part of lipid homeostasis and plays a fundamental role in the maintenance and regulation of male fertility.

In the testis, balanced androgen biogenesis and androgen aromatization to estrogen is crucial $[12,13]$. It is generally accepted that interstitial Leydig cells are the main sites of aromatization in the adult gonad. Aromatase expressional changes can exist under abnormal conditions. For example, in patients with sex cord tumors (Peutz-Jeghers syndrome), Sertoli cells of seminiferous epithelium show non-physiologically high expression of this enzyme [14]. It is important to add here that estrogen action has been implicated in different physiological and pathological testis states [13-17]. From the above evidence, the question arises about the specific contribution of adipokines and aromatase in lipid status control in normal Leydig cells and tumor Leydig cells as well as to molecule-molecule interactions that can be a cause or repercussion of the tumor. Panza et al. [18] showed molecular modulation of aromatase activity that leads to inhibition of tumor growth in rats in vivo. In rat tumor Leydig cells (R2C) interplay between transcription factor dosage-sensitive sex reversal adrenal hypoplasia critical region on chromosome $\mathrm{X}$ gene 1 and androgens resulted in aromatase inhibition and decreased tumor cell proliferation [19]. Similarly, insulin growth factor 1 through steroidogenic factor 1 inhibited estrogen-dependent tumor Leydig cell proliferation [20].

Activation of lipid metabolism is an early event in tumorigenesis [21]; however, the precise expression pattern of lipid balance-controlling molecules and their molecular mechanism of action 
in pathological tissues is not fully characterized. In past decades, Leydig cell tumors were rare, constituting $1-3 \%$ of cases in adults and $4-9 \%$ of cases in prepubertal children. Nowadays, an increase in the incidences $(14.7 \%)$ of this hormone-secreting tumor has been reported [22]. It is documented that Leydig cell tumors can secrete a variety of hormones e.g., testosterone, estrogen, and their derivatives [23]. Most Leydig cell tumors are benign but lately their malignant properties were reported [24,25]. In histology of this tumor different morphological types of steroidogenic cells as well as other cell types were observed [26]. In addition, Hibi et al. [27] reported the presence of adipocyte-like cells in tumor Leydig cell tissue.

Starting from the above findings, in this study, we investigated the expression of leptin, adiponectin and their receptors, and aromatase in human Leydig cell tumors. In addition, adipokine signaling proteins were examined to define the role these hormones play and whether there is a potential interaction between adipokines and aromatase. This study is a continuation of our prior reported data $[28,29]$ and provides further knowledge on the biology of Leydig cell tumors.

\section{Materials and Methods}

\subsection{Tissue Samples and Ethical Considerations}

Residual tissues from testicular biopsy (microdissection testicular sperm extraction by Schlegel, [30]) were collected at the nOvum Fertility Clinic, Warsaw, Poland from patients (31-45 year-old; $n=20$ ) diagnosed due to azoospermia (micronodules LCTs were recognized during surgery). After evaluation by pathologists and patient written informed consent according to the approval regulations by the National Commission of Bioethics at the Jagiellonian University in Krakow, Poland; permit no. 1072.6120.218.2017 and in accordance with the Declaration of Helsinki, specimens were used for the present study.

Tissue fragments were snap-frozen or fixed and paraffin-embedded, were stored and analyzed at the Department of Endocrinology, Institute of Zoology and Biomedical Research, Jagiellonian University in Krakow, Poland.

\subsection{Body Fat Measurement}

For body fat measurement, body mass index (BMI) based on height and weight of patients with the formula BMI = height $(\mathrm{kg}) /$ weight $\left(\mathrm{m}^{2}\right)$ and reference categories according to National Institutes of Health, Bethesda, MD, USA website https://www.nhlbi.nih.gov was used.

\subsection{Light andTtransmission Electron Microscopy Analyses}

Tissues were immersed in ice-cold pre-fixative containing $2 \%$ formaldehyde and $2.5 \%$ glutaraldehyde in $0.1 \mathrm{M}$ phosphate buffer, $\mathrm{pH}$ 7.3. The tissues were then rinsed and post-fixed in a mixture of $2 \%$ osmium tetroxide and $0.8 \%$ potassium ferrocyanide in the same buffer for $30 \mathrm{~min}$ at $4{ }^{\circ} \mathrm{C}$. After dehydration in the graded series of ethanol and acetone, the material was infiltrated in a freshly prepared mixture of acetone and Epon 812 (Serva, Heidelberg, Germany) and embedded in Epon 812. Semi-thin sections ( $0.7 \mu \mathrm{m}$ thick) were stained with $1 \%$ methylene blue and examined under a Leica DMR (Wetzlar, Germany) microscope. Ultrathin sections ( $80 \mathrm{~nm}$ thick) were contrasted with uranyl acetate and lead citrate and analyzed with a JEOL 2100 HT (Tokyo, Japan) TEM (for details see Bilinska et al. [31]).

\subsection{Western Blotting}

For quantification of protein expressions (Table 1) from LCTs proteins (as a control commercially available normal human Leydig cells; cat. No 10HU-103; ixCells Biotechnologies, San Diego CA, USA) were extracted in $50 \mu$ of radioimmunoprecipitation assay buffer (RIPA; Thermo Scientific, Inc. Rockford IL, USA) and protease inhibitor cocktail (Sigma Chemical Co., St. Louis, MO, USA). Concentration of proteins was determined with Bradford reagent (Bio-Rad Protein Assay; Bio-Rad 
Laboratories $\mathrm{GmbH}$, Munchen, Germany), using bovine serum albumin as a standard. Aliquots (50 $\mu$ g protein) of cell lysates were used for electrophoresis on $12 \%$ mini gel by standard SDS-PAGE procedures under reducing conditions and electrotransferred to polyvinylidene difluoride (PVDF) membranes (Millipore Corporate, MA, USA) by a semi-dry transfer cell (Bio-Rad, Munchen, Germany). Then, blots were blocked with $5 \%$ nonfat dry milk in TBS, $0.1 \%$ Tween 20 , overnight at $4{ }^{\circ} \mathrm{C}$ with shaking, followed by an incubation with respective antibodies (Table 1).

Table 1. Primary antibodies used for Western blot and immunohistochemistry.

\begin{tabular}{|c|c|c|c|}
\hline Antibody & Host Species & Vendor & Dilution \\
\hline adiponectin & goat & $\begin{array}{c}\text { Santa Cruz Biotechnology } \\
\text { cat no. sc-26496 }\end{array}$ & $\begin{array}{l}1: 50(\mathrm{IHC}) \\
1: 500(\mathrm{WB})\end{array}$ \\
\hline adiponectin receptor 1 & goat & $\begin{array}{c}\text { Santa Cruz Biotechnology } \\
\text { cat no. sc- } 46749\end{array}$ & $\begin{array}{l}1: 50(\mathrm{IHC}) \\
1: 500(\mathrm{WB})\end{array}$ \\
\hline cytochrome P450 aromatase & mouse & $\begin{array}{c}\text { Bio-Rad } \\
\text { cat no. MCA2077S }\end{array}$ & $\begin{array}{l}1: 50(\mathrm{IHC}) \\
1: 500(\mathrm{WB})\end{array}$ \\
\hline leptin & mouse & $\begin{array}{l}\text { Sigma-Aldrich } \\
\text { cat. no. L3160 }\end{array}$ & $\begin{array}{l}1: 50(\mathrm{IHC}) \\
1: 500(\mathrm{WB})\end{array}$ \\
\hline leptin receptor & mouse & $\begin{array}{l}\text { Santa Cruz Biotechnology } \\
\text { cat. no. sc- } 8391\end{array}$ & $\begin{array}{l}1: 50(\mathrm{IHC}) \\
1: 500(\mathrm{WB})\end{array}$ \\
\hline phospholipase C (PLC) & mouse & Abcam cat. no. ab243181 & 1:500 (WB) \\
\hline kinase Raf & rabbit & $\begin{array}{l}\text { Cell Signaling Technology } \\
\text { cat. no. } 9422\end{array}$ & 1:500 (WB) \\
\hline $\begin{array}{c}\text { extracellular signal-regulated } \\
\text { kinase (ERK1/2) }\end{array}$ & rabbit & $\begin{array}{l}\text { Cell Signaling Technology } \\
\text { cat. no. } 9102\end{array}$ & 1:1000 (WB) \\
\hline$\beta$-actin & mouse & $\begin{array}{l}\text { Sigma-Aldrich } \\
\text { cat. no. A2228 }\end{array}$ & 1:3000 (WB) \\
\hline
\end{tabular}

The membranes were washed and incubated with a secondary antibody conjugated with the horseradish-peroxidase labeled goat anti-mouse or goat anti-rabbit IgGs (Vector Labs., Burlingame, CA, USA) at a dilution 1:1000, for $1 \mathrm{~h}$ at RT. Immunoreactive proteins were detected by chemiluminescence with Western Blotting Luminol Reagent (Santa Cruz Biotechnology), and images were captured with a ChemiDoc XRS + System (Bio-Rad Laboratories). All immunoblots were stripped with stripping buffer containing $62.5 \mathrm{mM}$ Tris- $\mathrm{HCl}, 100 \mathrm{mM}$ 2-mercaptoethanol, and $2 \% \mathrm{SDS}(\mathrm{pH} 6.7)$ at $50{ }^{\circ} \mathrm{C}$ for $30 \mathrm{~min}$ and incubated with $\beta$-actin antibody. Each data point was normalized against its corresponding $\beta$-actin data point. Molecular masses were estimated by reference to standard proteins (Prestained SDS-PAGE Standards, Bio-Rad Labs, GmbH, Munchen, Germany). Quantitative analysis was performed for three separately repeated experiments using a public domain ImageJ software (National Institutes of Health, Bethesda, MD, USA) as described elsewhere [32]. The protein level within the control group was arbitrarily set as 1, against which the statistical significance of experimental groups was analyzed. The relative protein levels were expressed as arbitrary units.

\subsection{Immunohistochemistry}

To optimize immunohistochemical staining tissue sections both commercially available as a control (Zyagen, San Diego, CA, USA) and Leydig cell tumor sections were immersed in $10 \mathrm{mM}$ citrate buffer ( $\mathrm{pH} 6.0)$ and heated in a microwave oven $(2 \times 5 \mathrm{~min}, 700 \mathrm{~W})$. Thereafter, sections were immersed sequentially in $\mathrm{H}_{2} \mathrm{O}_{2}(3 \% ; v / v)$ for $10 \mathrm{~min}$ and normal goat serum $(5 \% ; v / v)$ for 30 min which were used as blocking solutions. After overnight incubation at $4{ }^{\circ} \mathrm{C}$ with primary antibodies listed in Table 1. Next respective biotinylated antibodies (anti-rabbit and anti-mouse IgGs; $1: 400$; Vector, Burlingame CA, USA) and avidin-biotinylated horseradish peroxidase complex (ABC/HRP; 1:100; Vectastain Elite $A B C$ Reagent, Vector Lab) were applied in succession. Bound antibody was visualized 
with 3,3'-diaminobenzidine (DAB) $(0.05 \%$; v/v; Sigma-Aldrich) as a chromogenic substrate. Controls included omission of primary antibody and substitution by irrelevant IgG.

\subsection{Statistics}

Three biological repeats of each sample and three independent experiments were performed. Each variable was tested using the Shapiro-Wilk W-test for normality. The homogeneity of variance was assessed with Levene's test. Comparisons were performed by one-way ANOVA, followed by Dunnett's post hoc test (GB-STAT software, v. 7.0; Dynamic Microsystems, Colesville, MD, USA) to determine the significant differences between proteins expression levels and BMI data. Statistical analyses were performed on raw data using Statistica 10 software (StatSoft Inc., Tulsa, OK, USA). Data were presented as means $\pm S$.D. Data were considered statistically significant at ${ }^{*} p<0.05,{ }^{* *} p<0.01$ and ${ }^{* * *} p<0.001$.

\section{Results}

\subsection{Body Mass Index in Patients with Leydig Cell Tumor}

Body mass index measurement of patients revealed that only seven of them had body fat in the reference range (means $\left.=23.85 \pm 2.02 \mathrm{~kg} / \mathrm{m}^{2}\right)$ while thirteen patients were overweight $(30.13 \pm 1.78$ $\left.\mathrm{kg} / \mathrm{m}^{2}\right)$.

Due to no significant differences in Leydig cell tumor protein expression between non-obese and obese patients, the results are presented as combined. Only dissimilarities found in the tumor cell ultrastructure analysis are presented as separate for both groups of patients.

\subsection{Topography and Ultrastructure of Leydig Cell Tumor}

Leydig cell tumor mass was clearly resembled from testicular tissue without lesions (Figure 1a). The tumor cells were intensively stained by methylene blue. They were tightly packed and non-arranged, thus cell shape and size differed distinctly (Figure 1b). In cells of the tumor mass, abundant lipid droplet content was found (especially in obese patients; Figure 1a,b when compared to non-obese, not shown). In the majority of the cells, lipid droplets were present as groups of medium and/or large droplets in both obese and non-obese patients. In addition, small lipid droplets were occasionally seen. Besides cells with altered nucleus shape (many various shape alterations) large cells featuring adipocytes with spherical nucleus and lipid accumulation were also seen (Figure 1b).

Ultrastructural analysis confirmed apparently affected Leydig cells (Figure 1c-e). In addition to normal organelles a number of variously shaped and sized vesicles within the cytoplasm of tumor cells were observed especially in obese patients (Figure 1a) when compared to non-obese ones (Figure 1d,e). Careful analyses of the micrographs taken under the higher magnification suggest that at least some of those vesicles represent lipid droplets and/or in their content some lipids are present.

\subsection{Expression of Leptin and Adiponectin and Their Receptors in Leydig Cell Tumor}

Significantly increased expression of leptin $(p<0.001)$ and its receptor $(p<0.01)$ as well as adiponectin $(p<0.01)$ and its receptor $(p<0.001)$ was revealed in Leydig cell tumors when compared to control (Figure 2). 

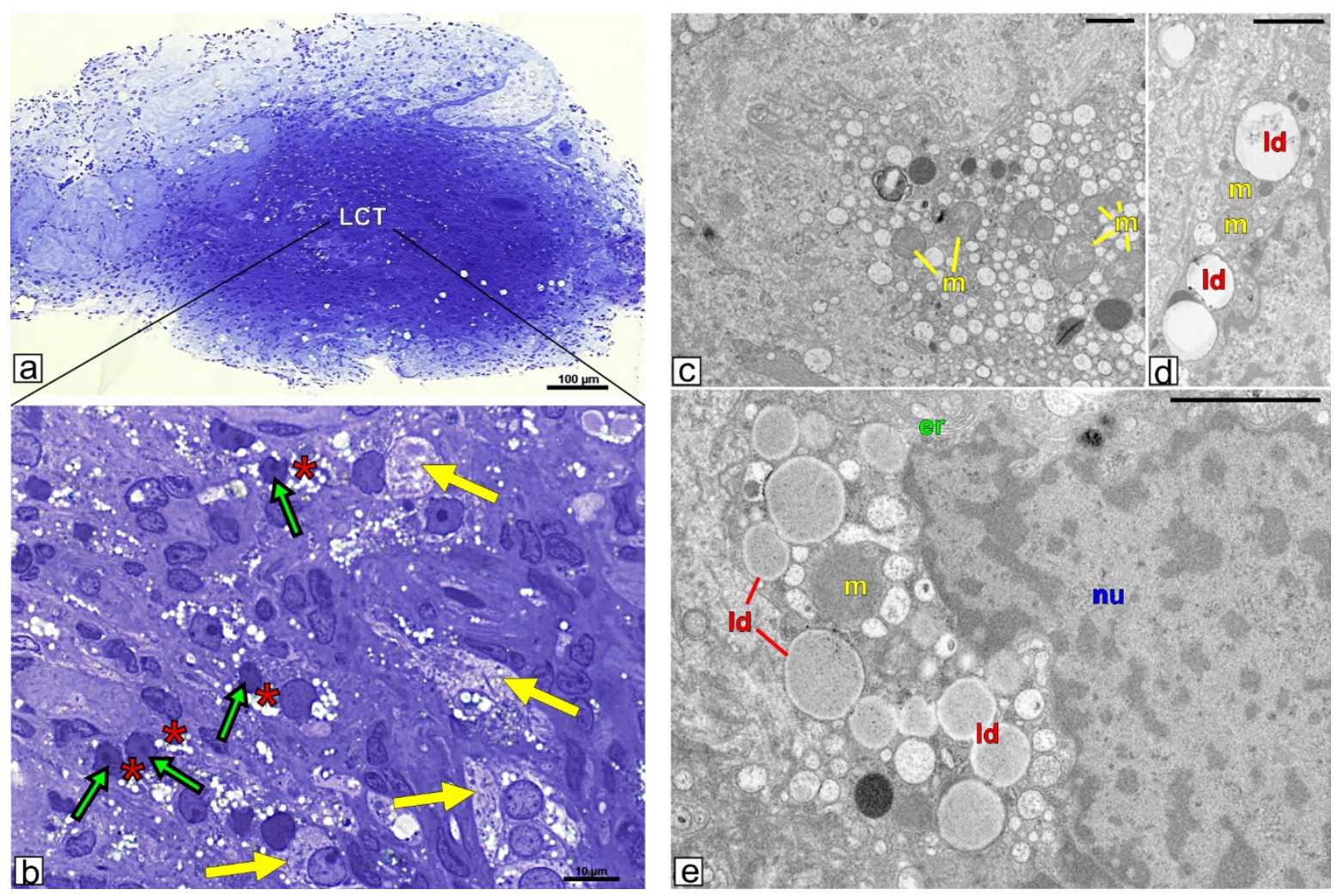

Figure 1. Ultrastructure of Leydig cell tumor. Representative microphotographs of semi-thin sections ( $\mathbf{a}$ and $\mathbf{b}$ higher magnification) and ultrathin ( $\mathbf{c}-\mathbf{e})$ of Leydig cell tumor. $(\mathbf{a}, \mathbf{b})$ Sections of testicular tissue of obese patient as representative for both obese and no-obese patients. Bars represent $1 \mu \mathrm{m}$. (c-e) Sections of Leydig cell of obese patient (c) and non-obese $(\mathbf{d}, \mathbf{e})$ patient. Analysis was performed on testicular blocks from at least three experimental groups. $(\mathbf{a}, \mathbf{b})$ green arrows depict Leydig cells (different morphological types); red arrows depict adipocyte-resembling cells; asterisks indicate lipid droplets in Leydig cells. (c-e) ld-lipid droplets; m-mitochondria; $n$-nucleus; er-rough endoplasmic reticulum.

\subsection{Localization of Leptin, Adiponectin and Their Receptors in Leydig Cell Tumor}

A positive signal for leptin and adiponectin was found in the cytoplasm of Leydig cells of the control (Figure 2A,C). Signal of similar intensity as in respective control, either for leptin or for adiponectin was found in each of the cells of the tumor (Figure 2B,D). While positive signal for leptin receptor was present in every Leydig cell of control tissue, it was present occasionally in cells of the tumor (Figure 2E,F). On the contrary, the adiponectin receptor was present only in a few cells of control but in the Leydig cell tumor, all cells showed its expression (Figure 2G,H). No positive staining was visible when the primary antibodies were omitted (inserts at $\mathrm{A}, \mathrm{C}, \mathrm{F}, \mathrm{H}$ ). 


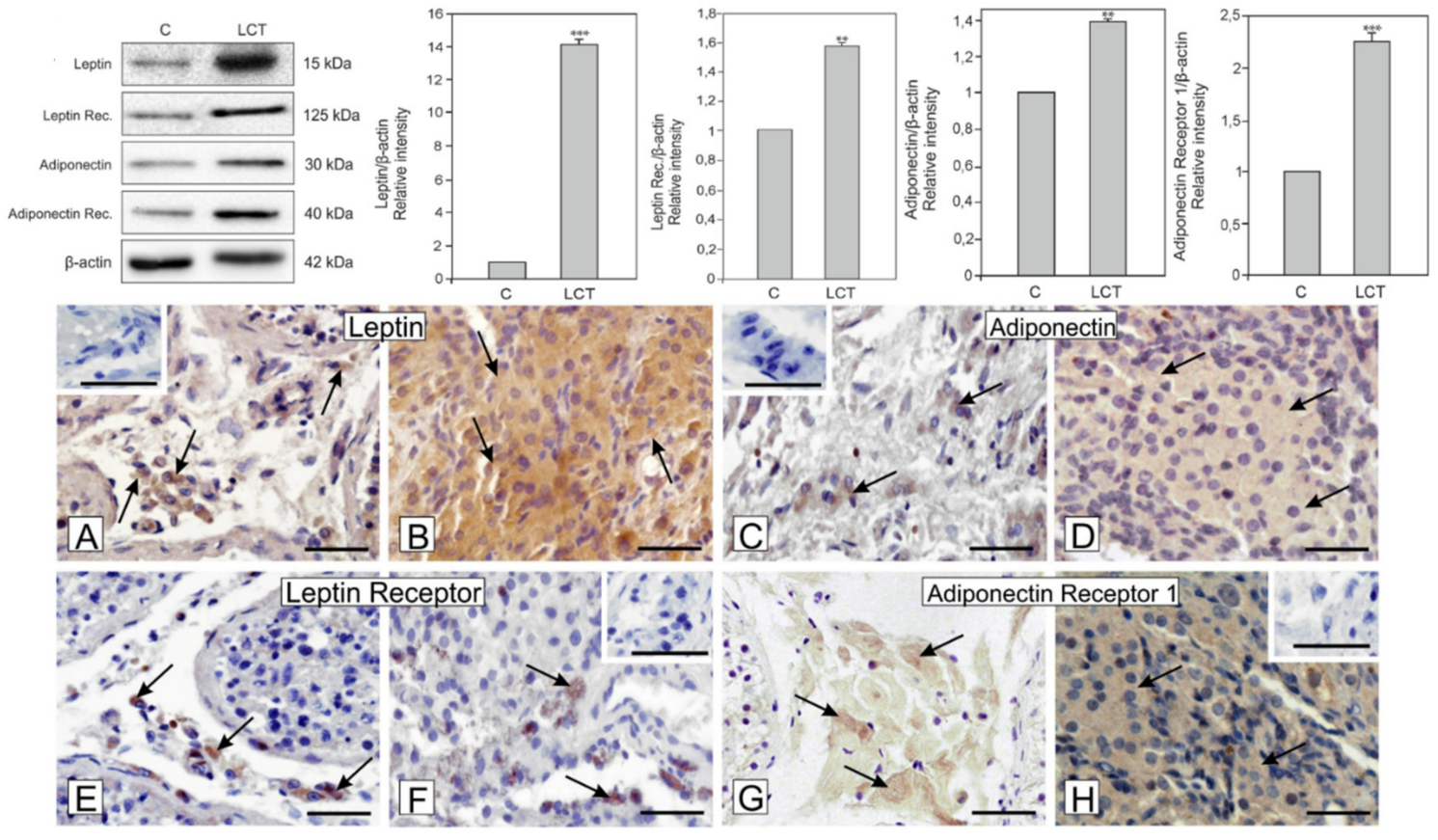

Figure 2. Expression (upper panel: blots and graphs) and localization of leptin and adiponectin and their receptors (lower panel: microphotographs) in a Leydig cell tumor. Representative blots and relative expression (arbitrary units) of qualitative expression of leptin, adiponectin, and their receptor proteins in Leydig cell of control (C) testis and Leydig cell tumor (LCT). The relative amount of respective proteins normalized to $\beta$-actin. Relative intensity of bands from three separate analyses is expressed as means. Asterisks show significant differences between expression of control and treated Leydig cells. Data is expressed as means \pm S.D. Values are denoted as ${ }^{* *} p<0.01$ and ${ }^{* * *} p<0.001$. Representative microphotographs of immunohistochemical localization of leptin (A,B), adiponectin $(\mathbf{C}, \mathbf{D})$, and their receptor proteins (E,F and G,H; respectively) in Leydig cell of control (C) testis and Leydig cell tumor (LCT). Counterstaining with hematoxylin. Bar $20 \mu \mathrm{m}$. Inserts at $(\mathbf{A}, \mathbf{C}, \mathbf{F}, \mathbf{H})-$ negative controls. Immunostaining was performed at least three times. Arrows- depict positive staining.

\subsection{Expression and Localization of Aromatase in Leydig Cell Tumor}

Marked increase in aromatase expression $(p<0.001)$ in Leydig cell tumors in comparison to control was found (Figure 3). In the Leydig cell tumor, very strong staining for aromatase when compared to the control where cells showed weak to moderate staining was observed (Figure 3a,b). No positive staining was visible when the primary antibody was omitted (insert at A).

3.6. Expression of Phospholipase C (PLC), Kinase Raf (Raf) and Extracellular signal-regulated kinase (ERK) in Leydig Cell Tumor

Markedly increased expression of PLC $(p<0.001)$, Raf $(p<0.01)$, and ERK $(p<0.001)$ in the Leydig cell tumor when compared to control was revealed (Figure 4). 

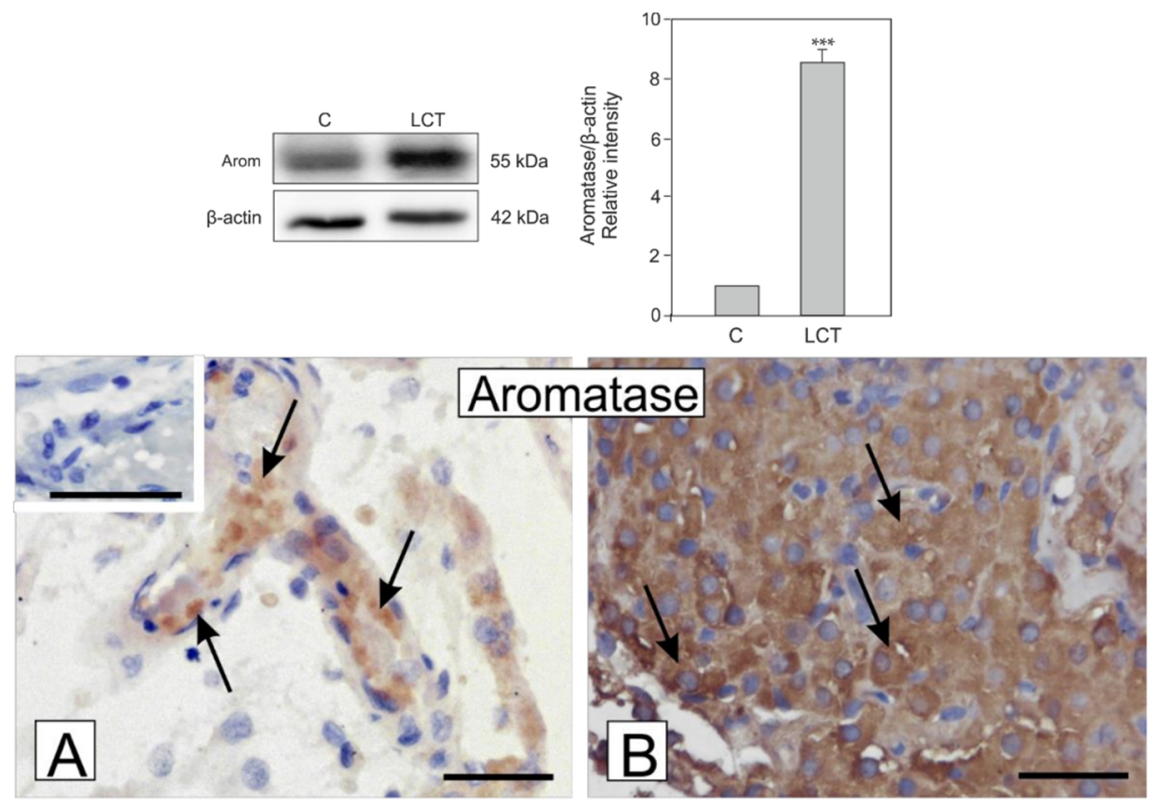

Figure 3. Expression (upper panel; blots and graph) and localization (lower panel; microphotographs) of aromatase in Leydig cell tumors. Representative blots and relative expression (arbitrary units) of qualitative expression of aromatase protein in Leydig cell of control testis (C) and a Leydig cell tumor (LCT). The relative amount of respective proteins normalized to $\beta$-actin. Relative intensity of bands from three separate analyses is expressed as means. Asterisks show significant differences between expression of control and treated Leydig cells. Data is expressed as means. Values are denoted as ${ }^{* * *} p<0.001$. Microphotographic documentation of DAB immunohistochemical localization of aromatase in Leydig cell of control testis (C) (A) and Leydig cell tumor (LCT) (B). Counterstaining with hematoxylin. Bar $20 \mu \mathrm{m}$. Insert at A-negative control. Immunostaining was performed at least three times. Arrows depict positive staining.
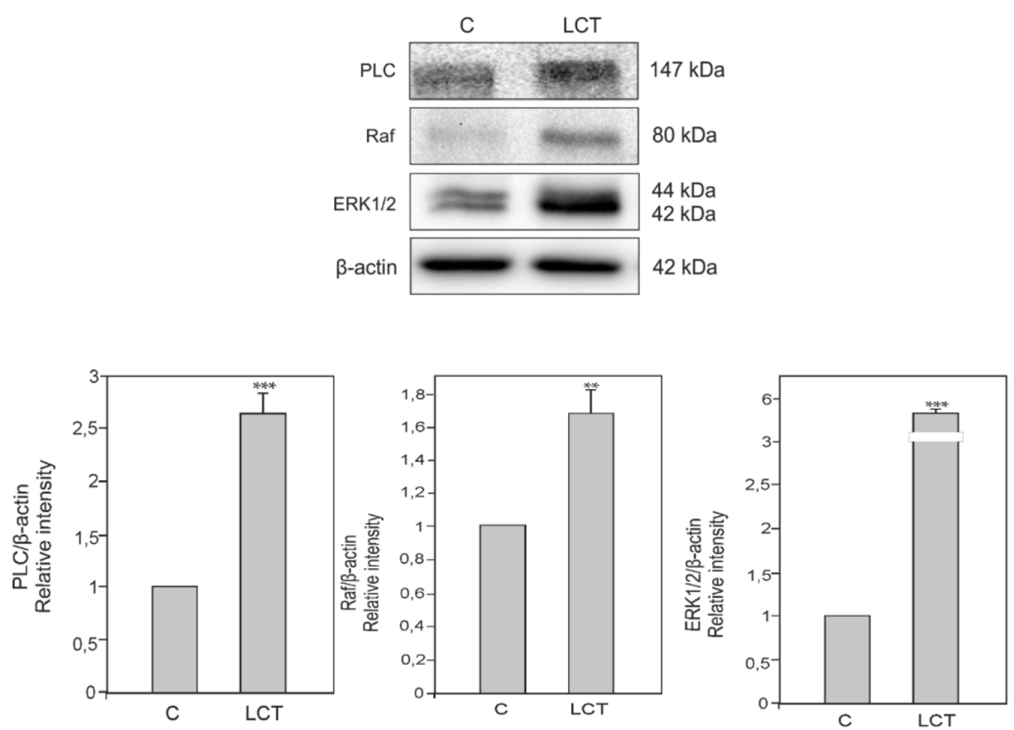

Figure 4. Expression of Phospholipase C (PLC), Kinase Raf (Raf) and Extracellular signal-regulated kinase (ERK) in Leydig cell tumors. Representative blots and relative expression (arbitrary units) of qualitative expression of PLC, Raf and ERK proteins in Leydig cell of control testis (C) and the Leydig cell tumor (LCT). The relative amount of respective proteins normalized to $\beta$-actin. Relative intensity of bands from three separate analyses is expressed as means. Asterisks show significant differences between expression of control and treated Leydig cells. Data is expressed as means. Values are denoted as ${ }^{* *} p<0.01$ and ${ }^{* * *} p<0.001$. 


\section{Discussion}

Estrogens promote, maintain, and control the distribution of adipose tissue and its metabolism. These hormones are potent anorectic agents reducing food intake and body weight. The feeding behavior was reported to be based on estrogen receptor $\alpha(E R \alpha)$ signaling in hypothalamic nuclei [33]. In ovariectomized rodents, estrogen similarly to leptin affected food intake and body weight [34]. Sex-dependent differences in levels of circulating leptin are well described [35]. In women, the concentration of leptin is always higher than in men [36]. Moreover, Tanaka et al. [37] demonstrated that estrogen application elevated the circulating leptin concentration in both humans and rats and increased leptin mRNA expression in adipose tissue in either in vitro or in vivo conditions. Adiponectin is one of adipokines that protects against obesity-related diseases in premenopausal women [38]. It was showed that oophorectomy of adult mice increased adiponectin level and reversed it by estradiol replacement [39]. On the other hand, the effect of adiponectin on bone metabolism is effectively suppressed by estradiol treatment [40].

Many lines of evidence confirmed the expression of both leptin and adiponectin in the interstitial tissue of rodent and human testis [41-44]. High expression of leptin receptor was correlated with the serum testosterone level [41]. New data by Panza et al. [18] indicated leptin as a key factor able to affect testicular seminoma progression, and its receptor as a potential target for novel treatments in this type of cancer. The study found high expression of leptin, adiponectin and their receptors in Leydig cell tumors, which can be considered as possible new diagnostics and therapeutic markers. However, no pronounced differences in expression of proteins studied here were found between those used for the study: tumor testicular tissues of azoospermic non-obese, and obese patients. It should be added that previously we reported increased perilipin expression and decreased steroidogenic acute regulating protein expression in these patients [27]. In addition, increased estradiol levels can reflect increased cholesterol content and/or perturbations in its processing in men with Leydig cell tumors. Epidemiological studies have highlighted associations between increased serum leptin levels and increased tumor growth, while adiponectin exhibited an inverse correlation with the development and progression of various cancers [45]. In addition, high expression of adipokines in Leydig cell tumors indicates intensive tumor metabolism that may lead to fast tumor growth and molecular changes, and cannot be excluded here. It was demonstrated that in the testis, adipokines regulate metabolism through both paracrine and autocrine action $[46,47]$. Low expression of peroxisome-proliferator activated receptor $\alpha, \beta$, and $\gamma(\operatorname{PPAR} \alpha, \beta$, and $\gamma)$ was confirmed in the Leydig cell tumor [28] and its regulation by adiponectin was confirmed [48]. Our recent findings showed different morphological types of Leydig cells present in tumor mass [28]. Herein, on ultrathin sections of the tumor, we confirmed also the presence of adipocyte-like cells. Of note, adipocyte-like cells can be an additional source of adipokines that signal in the tumor microenvironment. Tumor Leydig cells exhibited accumulation of lipids, which show subtle differences in their size and distribution in non-obese and obese patients visible at the ultrastructural level. Therefore, azoospermia in patients studied here may be a result of both Leydig cell dysfunction with involvement of increased body fat mass and lipid homeostasis-regulating hormones. It seems to be crucial to design a study that in detail will examine the mechanism and regulation of these pathological processes. Lipids and their metabolisms can have an effect on spermatogenesis and/or its efficiency, as well as both Leydig cell tumor development and its diagnosis/therapy. Obesity is one of the factors that impacts malignant breast tumor progression leading to alterations in levels of hormones, growth factors, and inflammatory markers e.g., cytokines and adipokines [49]. Moreover, recent findings by Hoffmann et al. [50] and Shuang et al. [51] in ovarian cancer cells report proliferation regulation by adiponectin through reversing effect of estradiol and enhancing proliferation by other adipokines. Stimulatory effect of leptin on cell growth and proliferation was observed in normal and cancer cells of the prostate [52]. On the basis of above facts, we postulate that adipokines alone or with estradiol can form pathological hormonal microenvironment effecting on mitosis resuming by Leydig cells in adult testis. In fact, healthy mature Leydig cells of adult lineage do not proliferate [53]. 
However, last finding revealed in vitro proliferation of sheep adult Leydig cells after metalloestrogen (selenium) treatment [54].

Concomitantly, in this study increased expression of leptin, adiponectin and their receptors as well as increased expression of aromatase was revealed. In our previous study, we reported an increased concentration of estradiol in Leydig cell tumors [55]. According to findings by Carpino et al. [14] the site of aromatization is restricted to and increased in the cell types that are compromised in the disease, as evidenced in Sertoli and Leydig cell tumors, and germ cell neoplasia. The localization of aromatase in altered cells suggests there are additional sources of estrogen production in the testis, which may function to cover tumor feed, energetic and metabolic needs, thus affecting its growth and development of further malignant and metastatic properties through maintaining of the local tumor microenvironment [49].

It was shown that expression of aromatase is proportional to body fat mass and causes more fat accumulation, thus forming a vicious cycle [56]. Excessive aromatase activity in adipose tissue leads to disturbed androgen/estrogen balance underlying obesity-related infertility. However, we were not able to reveal subtle differences in aromatase expression that might exist in tumor tissue between non-obese and obese patients. The effect of estrogens in testicular somatic cells is inhibitory, leading to reduced testosterone levels and sperm production; however, it has been observed that aromatase participates in the acquisition of sperm motility [56]. Obesity and the resulting chronic inflammatory state (we cannot ignore the possibility of the presence of cells of the immunological system in Leydig cell tumor masses) increase aromatase expression and estrogen synthesis. In the aromatase knockout (ArKO) mouse, levels of leptin are increasing within the time, along with two to four times more visceral adiposity [57]. The increase in aromatase immunoreactivity is observed during testis gestational development and it coincides with the period of Leydig cell precursors hyperplasia, a normal part of testis development essential to cover steroidogenic needs of the human fetal testis [58]. It seems also possible that in Leydig cell tumors, an increase of aromatase expression is responsible for lipid metabolism disturbance and in turn tumor transformation of normal cells. In fact, treatment with aromatase inhibitors is one of the therapeutic trials in women with breast carcinoma that affects lipid metabolism and inflammatory response [59].

What is more, in human Leydig cell tumors, varying expression patterns of both ER and non-canonical G-protein coupled estrogen receptor were observed $[14,28,29,60]$. These findings suggest that altered estrogen signalization with canonical and non-canonical estrogen receptors is involved in the biochemical properties of Leydig cell tumors and it should be under consideration as an important treatment target. In addition, attribution of the changes in organelle structure and function to estrogen and/or adipokine and/or lipid level and signaling also should be given special attention.

The mechanisms underlying the regulation of leptin and adiponectin concentrations by estrogen are not well-recognized. We showed for the first time that aromatase as well as phospholipase C (PLC) and kinases: Raf, ERK (extracellular signal-regulated kinase) can be part of adipokine signaling pathways in human Leydig cell tumors. It was found that estrogen enhanced leptin promoter activity in human placenta choriocarcinoma cell lines (JEG-3) [61]. Gambino et al. [62] demonstrated that estrogen-induced leptin expression in trophoblast cells through genomic and non-genomic mechanisms involved ER $\alpha$. In adipocytes cell line (3T3-L1), ER $\alpha$ induced leptin expression whereas ER $\beta$ inhibited it [63]. The ratio of ER $\alpha$ to $E R \beta$ expression may be an important potential regulatory factor in leptin expression, but it is disturbed in Leydig cell tumors [for review see 28,29]. We found an increased expression of PLC, Raf kinase, and ERK, that can indicate changes in signaling pathways involved and/or interacting with pleiotropic adipokine signaling [64]. In leptin-deficient mice PLC acted via phosphoinositide 3-kinase [65] while in muscle cells, adiponectin acted directly through PLC pathway [66] and in vascular smooth muscle cells, adiponectin used Raf-ERK pathway to regulate proliferation and apoptosis [45]. Data of the present study reflect that both proliferation and apoptosis occur in cells of the tumor and they are controlled via leptin and adiponectin together with PLC, Raf, and ERK. It was demonstrated that cancers acquire genetic mutations and epigenetic 
modifications that can result in the activation of oncogenes e.g., Raf and ERK, or can lead to inactivation of tumor suppressors [67]. Of note, through ERK pathway leptin influenced cumulus maturation and steroidogenic secretion in rabbit [68] and adiponectin in goat [69]. As mentioned above, incomplete data reflects distinct adipokine signaling pathways and/or single molecules of adipokine signaling can take part in Leydig cell regulation under central hypothalamus-pituitary-gonadal axis and via local lipid- and estrogen- created microenvironment [70,71].

\section{Conclusions}

Based on these results, we suggest that there is a link between adipokines and aromatase (estrogens) levels, signaling and adipokine-, estrogen- signaling interactions in Leydig cell tumors. Increased aromatase expression seems to be both cause and consequence of Leydig cell tumor initiation and/or progression. In Leydig tumor cells, aromatase and secreted estrogens can affect adipokine levels in the testicular interstitial tissue and/or body fat tissue leading to fertility disturbances. Elevated adipokine signaling with the implication of various transductional pathways in Leydig cell tumors showed that adipokines are also pleiotropic hormones in the pathological testis. Their interactions via endocrine/paracrine/autocrine pathways may contribute to the hormone (including estrogen) dependence of testicular tumorigenesis by stimulating Leydig cell proliferation, growth, and malignancy. Leptin and adiponectin, as well as estrogen production and their transductional routes, seem to be important for further considerations as potential targets for diagnosis and therapy of Leydig cell tumors and adipose tissue dysfunction [11,72], although more precise analyses e.g., ultrastructural and epigenetical, should be used for precise recognition of subtle differences that can exist in tumor tissue biochemistry between non-obese and obese patients. What is more, special attention should be paid to an explanation of the association of adiponectin, leptin, with infertility and BMI as it is still controversial $[73,74]$.

Author Contributions: All authors have equal contributions. Authors' contribution to the work described in the paper: M.D., E.G.-W., W.T., A.R., M.B., M.K.-B., J.K.W., B.J.P. performed the research, B.B., M.K.-B., I.K., analyzed the data. M.K.-B. designed the research study and wrote the paper. All authors have read and approved the final version of the manuscript.

Funding: This work was supported by a grant OPUS12 2016/23/B/NZ4/01788 from National Science Centre, Poland and partially by a grant from the Ministry of Science and Higher Education of Poland as part of the statutory activities of the University Centre of Veterinary Medicine, University of Agriculture in Krakow (a grant SUB/2020-080100-D016).

Acknowledgments: The Authors are grateful to Grzegorz Kapuscinski, FEBU (urologist), and Robert Wyban, MS (LAB-IVF) (nOvum Fertility Clinic, Warszawa) for cooperation and Piotr Pawlicki for technical help. The authors are very much grateful to the editor and anonymous reviewers for their constructive suggestions and helpful comments that allow improve this manuscript.

Conflicts of Interest: The authors declare that they have no conflict of interest.

\section{References}

1. Coelho, M.; Oliveira, T.; Fernandes, R. State of the art paper Biochemistry of adipose tissue: An endocrine organ. Arch. Med. Sci. 2013, 9, 191-200. [CrossRef]

2. Zhang, Y.; Proença, R.; Maffei, M.; Barone, M.; Leopold, L.; Friedman, J.M. Positional cloning of the mouse obese gene and its human homologue. Nature 1994, 372, 425-432. [CrossRef]

3. Friedman, J.M.; Halaas, J.L. Leptin and the regulation of body weight in mammals. Nature 1998, 395, 763-770. [CrossRef]

4. Rosenbaum, M.; Goldsmith, R.; Bloomfield, D.; Magnano, A.; Weimer, L.; Heymsfield, S.; Gallagher, D.; Mayer, L.; Murphy, E.; Leibel, R.L. Low-dose leptin reverses skeletal muscle, autonomic, and neuroendocrine adaptations to maintenance of reduced weight. J. Clin. Investig. 2005, 115, 3579-3586. [CrossRef]

5. Berg, A.H.; Combs, T.P.; Du, X.; Brownlee, M.; Scherer, P.E. The adipocyte-secreted protein Acrp30 enhances hepatic insulin action. Nat. Med. 2001, 7, 947-953. [CrossRef] 
6. Qi, Y.; Takahashi, N.; Hileman, S.M.; Patel, H.R.; Berg, A.H.; Pajvani, U.B.; Scherer, E.P.; Ahima, R.S. Adiponectin acts in the brain to decrease body weight. Nat. Med. 2004, 10, 524-529. [CrossRef]

7. Stern, J.H.; Rutkowski, J.M.; Scherer, P.E. Adiponectin, Leptin, and Fatty Acids in the Maintenance of Metabolic Homeostasis through Adipose Tissue Crosstalk. Cell Metab. 2016, 23, 770-784. [CrossRef]

8. Brunner, L.; Nick, H.-P.; Cumin, F.; Chiesi, M.; Baum, H.-P.; Whitebread, S.; Stricker-Krongrad, A.; Levens, N. Leptin is a physiologically important regulator of food intake. Int. J. Obes. 1997, 21, 1152-1160. [CrossRef]

9. Tatemoto, K.; Hosoya, M.; Habata, Y.; Fujii, R.; Kakegawa, T.; Zou, M.-X.; Kawamata, Y.; Fukusumi, S.; Hinuma, S.; Kitada, C.; et al. Isolation and Characterization of a Novel Endogenous Peptide Ligand for the Human APJ Receptor. Biochem. Biophys. Res. Commun. 1998, 251, 471-476. [CrossRef]

10. Tena-Sempere, M.; Manna, P.; Zhang, F.; Pinilla, L.; Gonzalez, L.; Dieguez, C.; Huhtaniemi, I.; Aguilar, E.; Thomas, G.; Baker, S.; et al. Molecular mechanisms of leptin action in adult rat testis: Potential targets for leptin-induced inhibition of steroidogenesis and pattern of leptin receptor messenger ribonucleic acid expression. J. Endocrinol. 2001, 170, 413-423. [CrossRef]

11. Leisegang, K.; Bouic, P.J.; Menkveld, R.; Henkel, R.R.; Bouic, P.J.; Menkveld, R.; Henkel, R.R. Obesity is associated with increased seminal insulin and leptin alongside reduced fertility parameters in a controlled male cohort. Reproduct. Biol. Endocrinol. 2014, 12, 34. [CrossRef] [PubMed]

12. Hess, R. Estrogen in the adult male reproductive tract: A review. Reprod. Boil. Endocrinol. 2003, 1, 52. [CrossRef] [PubMed]

13. Carreau, S.; Wolczynski, S.; Galeraud-Denis, I. Aromatase, oestrogens and human male reproduction. Philos. Trans. R. Soc. B: Boil. Sci. 2010, 365, 1571-1579. [CrossRef] [PubMed]

14. Carpino, A.; Rago, V.; Pezzi, V.; Carani, C.; Ando, S. Detection of aromatase and estrogen receptors (ER $\alpha$, ERß1, ERß2) in human Leydig cell tumor. Eur. J. Endocrinol. 2007, 157, 239-244. [CrossRef] [PubMed]

15. Gancarczyk, M.; Paziewska-Hejmej, A.; Carreau, S.; Tabarowski, Z.; Bilinska, B. Dose- and photoperiod-dependent effects of $17 \beta$-estradiol and the anti-estrogen ICI 182,780 on testicular structure, acceleration of spermatogenesis, and aromatase immunoexpression in immature bank voles. Acta Histochem. 2004, 106, 269-278. [CrossRef] [PubMed]

16. Meeker, J.D.; Ehrlich, S.; Toth, T.L.; Wright, D.L.; Calafat, A.M.; Trisini, A.T.; Ye, X.; Hauser, R. Semen quality and sperm DNA damage in relation to urinary bisphenol A among men from an infertility clinic. Reprod. Toxicol. 2010, 30, 532-539. [CrossRef]

17. Toppari, J.; Virtanen, H.E.; Main, K.M.; Skakkebaek, N.E. Cryptorchidism and hypospadias as a sign of testicular dysgenesis syndrome (TDS): Environmental connection. Birth Defects Res. Part A Clin. Mol. Teratol. 2010, 88, 910-919. [CrossRef]

18. Panza, S.; Malivindi, R.; Chemi, F.; Rago, V.; Giordano, C.; Barone, I.; Bonofiglio, D.; Gelsomino, L.; Giordano, F.; Andò, S.; et al. Glucocorticoid Receptor as a Potential Target to Decrease Aromatase Expression and Inhibit Leydig Tumor Growth. Am. J. Pathol. 2016, 186, 1328-1339. [CrossRef]

19. Maris, P.; Campana, A.; Barone, I.; Giordano, C.; Morelli, C.; Malivindi, R.; Sisci, D.; Aquila, S.; Rago, V.; Bonofiglio, D.; et al. Androgens Inhibit Aromatase Expression Through DAX-1: Insights Into the Molecular Link Between Hormone Balance and Leydig Cancer Development. Endocrinology 2015, 156, 1251-1262. [CrossRef]

20. Sirianni, R.; Chimento, A.; Malivindi, R.; Mazzitelli, I.; Andò, S.; Pezzi, V. Insulin-Like Growth Factor-I, Regulating Aromatase Expression through Steroidogenic Factor 1, Supports Estrogen-Dependent Tumor Leydig Cell Proliferation. Cancer Res. 2007, 67, 8368-8377. [CrossRef]

21. Seyfried, T.N.; Shelton, L.M. Cancer as a metabolic disease. Nutr. Metab. 2010, 7, 7. [CrossRef] [PubMed]

22. Gheorghisan-Galateanu, A.-A. Leydig cell tumors of the testis: A case report. BMC Res. Notes 2014, 7, 656. [CrossRef] [PubMed]

23. Due, W.; Dieckmann, K.-P.; Loy, V.; Stein, H. Immunohistological determination of oestrogen receptor, progesterone receptor, and intermediate filaments in Leydig cell tumours, Leydig cell hyperplasia, and normal Leydig cells of the human testis. J. Pathol. 1989, 157, 225-234. [CrossRef] [PubMed]

24. Tiwari, P.; Goel, A.; Sharma, P.; Kumar, S.; Vijay, M.; Dutta, A. Leydig cell tumor with mediastinal and lung metastasis. Saudi J. Kidney Dis. Transplant. 2011, 22, 354-356.

25. Vasilakaki, T.; Michalis, L.; Skafida, E.; Arkoumani, E.; Delliou, E.; Grammatoglou, X.; Kontovourkis, P.; Papamichail, V.; Stamatiou, K. An unusual case of unilateral malignant leydig cell tumour of the testis. Case Rep. Oncol. 2011, 4, 132-135. [CrossRef] [PubMed] 
26. Richmond, I.; Banerjee, S.S.; Eyden, B.P.; Sissons, M.C. Sarcomatoid Leydig cell tumor of the testis. Histopathology 1995, 27, 578-580. [CrossRef]

27. Hibi, H.; Yamashita, K.; Sumitomo, M.; Asada, Y. Leydig cell tumor of the testis, presenting with azoospermia. Reprod. Med.Biol. 2017, 16, 392-395. [CrossRef]

28. Kotula-Balak, M.; Gorowska-Wojtowicz, E.; Milon, A.; Pawlicki, P.; Tworzydlo, W.; Płachno, B.J.; Krakowska, I.; Hejmej, A.; Wolski, J.K.; Bilinska, B. Towards understanding leydigioma: Do G protein-coupled estrogen receptor and peroxisome proliferator-activated receptor regulate lipid metabolism and steroidogenesis in Leydig cell tumors? Protoplasma 2020, 1-15. [CrossRef]

29. Gorowska-Wojtowicz, E.; Duliban, M.; Kudrycka, M.; Dutka, P.; Pawlicki, P.; Milon, A.; Zarzycka, M.; Placha, W.; Kotula-Balak, M.; Ptak, A.; et al. Leydig cell tumorigenesis-Implication of G-coupled estrogen receptor/peroxisome proliferator-activated receptor interaction and xenoestrogen exposure. In vivo and in vitro appraisal. Tissue Cell 2019, 61, 51-60. [CrossRef]

30. Schlegel, P.N.; Li, P.S. Microdissection TESE: Sperm retrieval in non-obstructive azoospermia. Hum. Reprod. Updat. 1998, 4. [CrossRef]

31. Bilinska, B.; Hejmej, A.; Kotula-Balak, M. Preparation of Testicular Samples for Histology and Immunohistochemistry. In Advanced Structural Safety Studies; Springer Science and Business Media LLC: Berlin, Germany, 2018; Volume 1748, pp. 17-36.

32. Smolen, A.J. Image analytic techniques for quantification of immunocytochemical staining in the nervous system. In Methods in Neurosciences; Academic Press: San Diego, CA, USA, 1990; pp. 208-229.

33. Brown, L.M.; Gent, L.; Davis, K.; Clegg, D.J. Metabolic impact of sex hormones on obesity. Brain Res. 2010, 1350, 77-85. [CrossRef] [PubMed]

34. Pelleymounter, M.A.; Baker, M.B.; McCaleb, M. Does estradiol mediate leptin's effects on adiposity and body weight? Am. J. Physiol. Content 1999, 276, E955-E963. [CrossRef]

35. Fungfuang, W.; Terada, M.; Komatsu, N.; Moon, C.; Saito, T.R. Effects of estrogen on food intake, serum leptin levels and leptin mRNA expression in adipose tissue of female rats. Lab. Anim. Res. 2013, 29, 168-173. [CrossRef]

36. Saad, M.F.; Damani, S.; Gingerich, R.L.; Riad-Gabriel, M.G.; Khan, A.; Boyadjian, R.; Jinagouda, S.D.; el-Tawil, K.; Rude, R.K.; Kamdar, V. Sexual dimorphism in plasma leptin concentration. J. Clin. Endocrinol. Metab. 1997, 82, 579-584. [CrossRef]

37. Tanaka, M.; Nakaya, S.; Kumai, T.; Watanabe, M.; Tateishi, T.; Shimizu, H.; Kobayashi, S. Effects of estrogen on serum leptin levels and leptin mRNA expression in adipose tissue in rats. Horm. Res. 2001, 56, 98-104. [CrossRef]

38. Kunnari, A.; Santaniemi, M.; Jokela, M.; Karjalainen, A.H.; Heikkinen, J.; Ukkola, O.; Kesäniemi, Y.A. Estrogen replacement therapy decreases plasma adiponectin but not resistin in postmenopausal women. Metabolism 2008, 57, 1509-1515. [CrossRef]

39. Lizcano, F.; Guzmán, G. Estrogen Deficiency and the Origin of Obesity during Menopause. BioMed Res. Int. 2014, 2014, 1-11. [CrossRef]

40. Wang, Q.-P.; Yang, L.; Li, X.-P.; Xie, H.; Liao, E.-Y.; Wang, M.; Luo, X.-H. Effects of $17 \beta$-estradiol on adiponectin regulation of the expression of osteoprotegerin and receptor activator of nuclear factor- $\mathrm{kB}$ ligand. Bone 2012, 51, 515-523. [CrossRef]

41. Ishikawa, T.; Fujioka, H.; Ishimura, T.; Takenaka, A.; Fujisawa, M. Expression of leptin and leptin receptor in the testis of fertile and infertile patients. Andrologia 2007, 39, 22-27. [CrossRef]

42. Herrid, M.; O'Shea, T.; McFarlane, J.R. Ontogeny of leptin and its receptor expression in mouse testis during the postnatal period. Mol. Reprod. Dev. 2008, 75, 874-880. [CrossRef]

43. Kawwass, J.F.; Summer, R.; Kallen, C. Direct effects of leptin and adiponectin on peripheral reproductive tissues: A critical review. Mol. Hum. Reprod. 2015, 21, 617-632. [CrossRef] [PubMed]

44. Milon, A.; Pawlicki, P.; Rak, A.; Mlyczynska, E.; Płachno, B.J.; Tworzydlo, W.; Gorowska-Wojtowicz, E.; Bilinska, B.; Kotula-Balak, M. Telocytes are localized to testis of the bank vole (Myodes glareolus) and are affected by lighting conditions and G-coupled membrane estrogen receptor (GPER) signaling. Gen. Comp. Endocrinol. 2018, 271, 39-48. [CrossRef] [PubMed]

45. Vansaun, M.N. Molecular pathways: Adiponectin and leptin signaling in cancer. Clin. Cancer Res. 2013, 19, 1926-1932. [CrossRef] 
46. Caminos, J.E.; Nogueiras, R.; Gaytán, F.; Pineda, R.; González, C.R.; Barreiro, M.L.; Castaño, J.P.; Malagón, M.M.; Pinilla, L.; Toppari, J.; et al. Novel expression and direct effects of adiponectin in the rat testis. Endocrinology 2008, 149, 3390-3402. [CrossRef]

47. Martin, L.J. Implications of adiponectin in linking metabolism to testicular function. Endocrine 2014, 46, 16-28. [CrossRef]

48. Yamauchi, T.; Kamon, J.; Waki, H.; Terauchi, Y.; Kubota, N.; Hara, K.; Mori, Y.; Ide, T.; Murakami, K.; Tsuboyama-Kasaoka, N.; et al. The fat-derived hormone adiponectin reverses insulin resistance associated with both lipoatrophy and obesity. Nat. Med. 2001, 7, 941-946. [CrossRef]

49. Schech, A.; Yu, S.; Goloubeva, O.; McLenithan, J.; Sabnis, G. A nude mouse model of obesity to study the mechanisms of resistance to aromatase inhibitors. Endocr. Relat. Cancer 2015, 22, 645-656. [CrossRef]

50. Hoffmann, M.; Gogola, J.; Ptak, A. Adiponectin Reverses the Proliferative Effects of Estradiol and IGF-1 in Human Epithelial Ovarian Cancer Cells by Downregulating the Expression of Their Receptors. Horm. Cancer 2018, 9, 166-174. [CrossRef] [PubMed]

51. Shuang, L.; Jidong, W.; Hongjuan, P.; Zhenwei, Y. Effects of apelin on proliferation and apoptosis in rat ovarian granulosa cells. Clin. Exp. Obstet. Gynecol. 2016, 43, 409-413.

52. Szyszka, M.; Tyczewska, M.; Milecka, P.; Jopek, K.; Celichowski, P.; Malendowicz, L.K.; Rucinski, M. Effects of leptin on leptin receptor isoform expression and proliferative activity in human normal prostate and prostate cancer cell lines. Oncol. Rep. 2017, 39, 182-192. [CrossRef]

53. Mendis-Handagama, C.; Ariyaratne, H.S. Differentiation of the adult Leydig cell population in the postnatal testis. Boil. Reprod. 2001, 65, 660-671. [CrossRef]

54. Shi, L.; Song, R.; Yao, X.; Ren, Y. Effects of selenium on the proliferation, apoptosis and testosterone production of sheep Leydig cells in vitro. Theriogenology 2017, 93, 24-32. [CrossRef]

55. Zumoff, B.; Strain, G.W.; Kream, J.; O'Connor, J.; Levin, J.; Fukushima, D.K. Obese young men have elevated plasma estrogen levels but obese premenopausal women do not. Metabolism 1981, 30, 1011-1014. [CrossRef]

56. Xu, X.; Sun, M.; Ye, J.; Luo, D.; Su, X.; Zheng, D.; Feng, L.; Gao, L.; Yu, C.; Guan, Q. The Effect of Aromatase on the Reproductive Function of Obese Males. Horm. Metab. Res. 2017, 49, 572-579. [CrossRef]

57. Simpson, E.R.; Misso, M.; Hewitt, K.N.; Hill, R.A.; Boon, W.C.; Jones, M.E.; Kovacic, A.; Zhou, J.; Clyne, C.D. Estrogen-The good, the bad, and the unexpected. Endocr. Rev. 2005, 26, 322-330. [CrossRef]

58. Haverfield, J.T.; Ham, S.; Brown, K.A.; Simpson, E.R.; Meachem, S.J. Teasing out the role of aromatase in the healthy and diseased testis. Spermatogenesis 2011, 1, 240-249. [CrossRef]

59. Melichar, B.; Kalábová, H.; Krcmová, L.; Urbánek, L.; Hyspler, R.; Solichová, D.; Melicharová, K.; Pecka, M.; Zadák, Z. Effect of aromatase inhibitors on lipid metabolism, inflammatory response and antioxidant balance in patients with breast carcinoma. Anticancer. Res. 2009, 29, 3337-3346.

60. Rago, V.; Romeo, F.; Giordano, F.; Maggiolini, M.; Carpino, A. Identification of the estrogen receptor GPER in neoplastic and non-neoplastic human testes. Reprod. Boil. Endocrinol. 2011, 9, 135. [CrossRef]

61. O’Neil, J.S.; Burow, M.E.; Green, A.E.; McLachlan, J.A.; Henson, M.C. Effects of estrogen on leptin gene promoter activation in MCF-7 breast cancer and JEG-3 choriocarcinoma cells: Selective regulation via estrogen receptors alpha and beta. Mol. Cell. Endocrinol. 2001, 176, 67-75. [CrossRef]

62. Gambino, Y.P.; Maymó, J.L.; Pérez, A.P.; Dueñas-Díez, J.-L.; Sánchez-Margalet, V.; Calvo, J.C.; Varone, C. 17Beta-Estradiol Enhances Leptin Expression in Human Placental Cells Through Genomic and Nongenomic Actions1. Boil. Reprod. 2010, 83, 42-51. [CrossRef]

63. Yi, K.W.; Shin, J.H.; Seo, H.S.; Lee, J.K.; Oh, M.J.; Kim, T.; Saw, H.S.; Kim, S.H.; Hur, J.Y. Role of estrogen receptor-alpha and -beta in regulating leptin expression in 3T3-L1 adipocytes. Obesity 2008, 16, 2393-2399. [CrossRef] [PubMed]

64. Frühbeck, G. Intracellular signalling pathways activated by leptin. Biochem. J. 2005, 393, 7-20. [CrossRef] [PubMed]

65. Lee, J.-W.; Swick, A.G.; Romsos, D.R. Leptin constrains phospholipase C-protein kinase C-induced insulin secretion via a phosphatidylinositol 3-kinase-dependent pathway. Exp. Boil. Med. 2003, 228, 175-182. [CrossRef] [PubMed]

66. Zhou, L.; Deepa, S.S.; Etzler, J.C.; Ryu, J.; Mao, X.; Fang, Q.; Liu, D.D.; Torres, J.M.; Jia, W.; Lechleiter, J.D.; et al. Adiponectin activates AMP-activated protein kinase in muscle cells via APPL1/LKB1-dependent and phospholipase $\mathrm{C} / \mathrm{Ca} 2+/ \mathrm{Ca} 2+/$ calmodulin-dependent protein kinase kinase-dependent pathways. J. Biol. Chem. 2009, 284, 22426-224350. [CrossRef] 
67. Zhang, W.; Shu, C.; Li, Q.; Li, M.; Li, X. Adiponectin affects vascular smooth muscle cell proliferation and apoptosis through modulation of the mitofusin-2-mediated Ras-Raf-Erk1/2 signaling pathway. Mol. Med. Rep. 2015, 12, 4703-4707. [CrossRef]

68. Arias-Alvarez, M.; García-García, R.M.; Torres-Rovira, L.; González-Bulnes, A.; Rebollar, P.G.; Lorenzo, P.L. Influence of leptin on in vitro maturation and steroidogenic secretion of cumulus-oocyte complexes through JAK2/STAT3 and MEK 1/2 pathways in the rabbit model. Reproduction 2010, 139, 523-532. [CrossRef]

69. Gomes, E.T.; Costa, J.A.S.; Silva, D.M.F.; Al Shebli, W.; Azevedo, M.L.; Monteiro, P.L.J.; Araújo Silva, R.A.J.; Santos Filho, A.S.; Guerra, M.M.P.; Bartolomeu, C.C. Effects of adiponectin during in vitro maturation of goat oocytes: MEK 1/2 pathway and gene expression pattern. Reprod. Domest. Anim. 2018, 53, 1323-1329. [CrossRef]

70. Donadeu, F.X.; Esteves, C.L.; Doyle, L.K.; Walker, C.A.; Schauer, S.N.; Diaz, C.A. Phospholipase C $\beta 3$ mediates LH-induced granulosa cell differentiation. Endocrinology 2011, 152, 2857-2869. [CrossRef]

71. Kadooka, K.; Sato, M.; Matsumoto, T.; Kuhara, S.; Katakura, Y.; Fujimura, T. Pig testis extract augments adiponectin expression and secretion through the peroxisome proliferator-activated receptor signaling pathway in 3T3-L1 adipocytes. Cytotechnology 2018, 70, 983-992. [CrossRef]

72. Frühbeck, G.; Catalán, V.; Rodríguez, A.; Gómez-Ambrosi, J. Adiponectin- leptin ratio: A promising index to estimate adipose tissue dysfunction. Relation with obesity-associated cardiometabolic risk. Adipocyte 2018, 7, 57-62. [CrossRef]

73. Awede, B.; Adovoekpe, D.; Adehan, G.; Macfarlane, N.G.; Azonbakin, S.; Dossou, E.; Amoussou-Guénou, M.; Djrolo, F. Adiponectin, in contrast to leptin, is not associated with body mass index, waist circumference and HOMA-IR in subjects of a west-African population. Physiol. Rep. 2018, 6, e13718. [CrossRef] [PubMed]

74. Dutta, S.; Sengupta, P.; Biswas, A. Adiponectin in male reproduction and infertility. Asian Pac. J. Reprod. 2019, 8, 244. [CrossRef]

(C) 2020 by the authors. Licensee MDPI, Basel, Switzerland. This article is an open access article distributed under the terms and conditions of the Creative Commons Attribution (CC BY) license (http://creativecommons.org/licenses/by/4.0/). 